\title{
IMPLEMENTASI AKAD BERPOLA KERJA SAMA DALAM PRODUK KEUANGAN DI BANK SYARIAH (Kajian Mudharabah dan Musyarakah dalam Hukum Ekonomi Syariah)
}

\author{
Muhammad Syarif Hidayatullah*1 \\ *I UIN ANTASARI BANJARMASIN \\ Email: syarif.muhammad849@gmail.com
}

\begin{abstract}
Abstrak
Bank Syariah sebagai lembaga keuangan yang operasionalnya berdasarkan prinsip syariah, maka dalam sistem produk yang ditawarkan menggunakan akad-akad syariah. Dari beragamnya akad yang dapat diterapkan di bank syariah terdapat akad dengan pola kerja sama, selain pola jual-beli dan sewa-menyewa/upah mengupah yang menjadi landasan komersial bisnis. Akad pola kerja sama tersebut adalah mudharabah dan musyarakah. Penelitian ini bertujuan menganalisis akad pola kerja sama di bank syariah dalam perspektif hukum ekonomi syariah. Hasil pembahasan yakni operasional produk yang ditawarkan bank syariah dengan pola mudharabah terdapat pada produk pendanaan dan pembiayaan, sedangkan musyarakah terbatas pada pembiayaan. Implementasi akad mudharabah dan musyarakah di Bank Syariah dalam kajian hukum ekonomi syariah adalah boleh dilaksanakan dan memiliki legalitas atas dasar prisip syariah, sebab akad mudharabah dan musyarakah merupakan akad berpola kerja sama yang sesuai dengan tuntunan akad syariah dalam fikih muamalah.
\end{abstract}

Kata Kunci: Mudharabah; Musyarakah; Produk Keuangan; Bank Syariah, Hukum Ekonomi Syariah

\section{Abstract}

Islamic banks as financial institutions whose operations are based on sharia principles, then in the product system offered using sharia contracts. Of the variety of contracts that can be applied in Islamic banks, there are contracts with cooperation patterns, in addition to the buying and selling and leasing / wage payment patterns which form the basis of commercial business. The contract for the cooperation pattern is mudharabah and musyarakah. This study aims to analyze the contract pattern of cooperation in Islamic banks in the perspective of Islamic economic law. The results of the discussion are operational products offered by Islamic banks with mudharabah patterns found in funding and financing products, while musyarakah is limited to financing. The implementation of mudharabah and musyarakah contracts in Sharia Banks in the study of sharia economic law is permissible and has legality on the basis of sharia principles, because mudharabah and musyarakah contracts are cooperative-patterned agreements in accordance with the guidance of sharia contracts in muamalah figh.

Keywords: Mudharabah; Musyarakah; Financial Product; Islamic Bank, Islamic Economic Law

\section{PENDAHULUAN}

Salah satu cara untuk mencapai sebuah keadilan dan kejujuran adalah dengan adanya kerja sama antara pemilik modal dan seseorang yang sering disebut dengan bagi hasil, yang mana dilandasi pula oleh rasa tolong menolong. Sebab ada orang yang mempunyai modal, tetapi tidak mempunyai keahlian dalam menjalankan roda perusahaan. Namun ada pula mereka yang lebih memilih menjalankan usaha dengan cara berserikat dengan orang lain yang memiliki tujuan atau usaha yang sama. Dengan cara ini, mereka semua yang mengikatkan diri berhak bertindak hukum terhadap harta itu, dan berhak mendapatkan keuntungan sesuai dengan persetujuan yang disepakati. Konsep yang pertama (kerjasama pemilik modal dan pengelola modal) dalam ekonomi Islam disebut akad mudharabah dan konsep yang kedua (kerjasama perserikatan antara para pemilik modal) disebut musyarakah.

Kedua akad berpola kerja sama ini, dalam perkembangannya telah dipraktikkan tidak lagi pada tatanan personal, namun sudah merambah praktik institusional. Dalam produk keuangan kontemporer, maka kedua akad tersebut menjadi salah satu model transaksi di Bank Syariah sebagai salah lembaga keuangan modern berbasis syariah saat ini. Dengan operasional yang berdasar pada prinsip syariah (hukum Islam), maka aktivitas ekonomi yang diterapkan Bank Syariah, termasuk dalam model akad berpola kerja sama haruslah dalam ruang lingkup struktur hukum ekonomi syariah, karena problematika dunia usaha termasuk problematika yang diperhatikan oleh ajaran syariat Islam yang suci. 


\section{PEMBAHASAN}

I. Mudharabah

a. Definisi Mudharabah

Secara bahasa mudharabah berasal dari kata dharb, berarti memukul atau berjalan. Pengertian memukul atau berjalan ini lebih tepatnya adalah proses seseorang memukulkan kakinya dalam menjalankan usaha.

Adapun menurut istilah mudharabah adalah persetujuan kongsi antara harta dari salah satu pihak dengan kerja dari pihak lain atau sederhananya merupakan akad kerja sama usaha antara dua pihak dimana pihak pertama (shabib al-mal) menyediakan seluruh modal, sedangkan pihak lain menjadi pengelola, dan keuntungan usaha dibagi menurut kesepakatan nisbah bagi hasil yang dituangkan dalam perjanjian, sedangkan apabila rugi ditanggung oleh pemilik modal selama kerugian itu bukan akibat kelalaian si pengelola.

b. Landasan Hukum Islam tentang Mudharabah

I) Al-Quran

QS. an-Nisa/4: 29

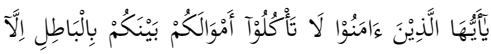

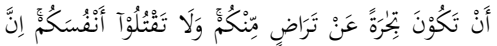

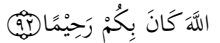

"Hai orang-orang yang beriman, janganlah kamu saling memakan harta sesamamu dengan jalan yang batil, kecuali dengan jalan perniagaan yang Berlaku dengan suka samasuka di antara kamu. dan janganlah kamu membunuh dirimu; Sesungguhnya Allah adalah Maha Penyayang kepadamu."

QS. al-Jumu'ah/62: 10

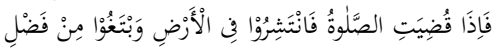

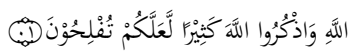

"Apabila telah ditunaikan shalat, Maka bertebaranlah kamu di muka bumi; dan carilah karunia Allah dan ingatlah Allah banyak-banyak supaya kamu beruntung."

\section{2) Al-Hadits}

Hadits riwayat Ibnu Majah dari Shuhaib:

$$
\begin{aligned}
& \text { قَالَ رَسُوْلُ المَلَّهِ }
\end{aligned}
$$

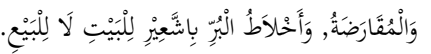

Rasulullah saw. bersabda: "ada tiga hal yang mengandung berkah, yaitu jual beli secara tangguh, muqaradhah (mudharabah), dan mencampur gandum dan jewawut untuk keperluan rumah tangga, bukan untuk dijual." (HR. Ibnu Majah)

Hadits riwayat Thabrani dalam Mu'jam alAusath, dari Ibnu Abbas:

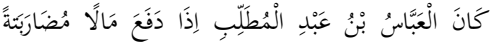

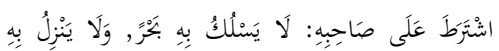

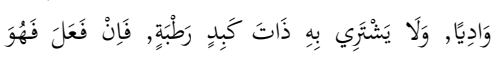

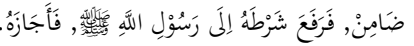

Abbas bin Abdul Muthalib jika menyerahkan harta sebagai mudharabah, ia mensyaratkan kepada pengelola dananya agar tidak mengarungi lautan, tidak menuruni lembah serta tidak membeli hewan ternak. Jika persyaratan itu dilanggar, maka pengelola harus menanggung risikonya. Ketika persyaratan Abbas didengar Rasulullah saw., beliau membenarkannya. (HR. Thabrani)

3) Ijma'

Mudharabah disyariatkan berdasarkan ijma' (kesepakatan) para sahabat dan berdasarkan kesepakatan para imam yang menyatakan kebolehannya. Hal itu, pada zaman Rasulullah saw., telah diketahui dan hanya tinggal ditetapkan saja.

4) Qiyas

Transaksi mudharabah diqiyaskan dengan transaksi musaqah.

c. Jenis-jenis mudharabah

Mudharabah terbagi menjadi dua jenis, yaitu mudharabah mutlaqah dan mudharabah muqayyadah.

I) Mudharabah Mutlaqah

Mudharabah mutlaqah (investasi tidak terikat) adalah jenis mudharabah dengan pemilik modal (shahibul mal) memberikan kebebasan penuh kepada pengelola untuk mengelola modal tersebut tanpa adanya batasan seperti jenis usaha atau industri tertentu.

2) Mudharabah Muqayyadah

Mudharabah muqayyadah (investasi terikat) adalah jenis mudharabah dengan pemilik modal (shahibul mal) memberikan batasan kepada pengelola modal (mudharib) untuk mengelola modalnya dengan persyaratan yang ditentukan, contohnya persyaratan jenis usaha atau industri yang dijalankan.

d. Rukun dan Syarat mudharabah

Rukun dari akad mudharabah yang harus dipenuhi dalam transaksi ada beberapa, yaitu:

I) Pelaku akad, yaitu shahibul mal (pemodal) adalah pihak yang memiliki modal tetapi tidak bisa berbisnis, dan mudharib (pengelola) adalah pihak yang pandai berbisnis, tetapi tidak memiliki modal. 
2) Objek akad yaitu modal (mal), kerja (dharabah), dan keuntungan (ribh)

3) Shighah, yaitu ijab dan qabul.

Sementara itu, syarat-syarat khusus yang harus dipenuhi dalam mudharabah terdiri dari syarat modal dan keuntungan. Syarat modal yaitu:

I) Modal harus berupa uang, bukan barang. Ketentuan ini sebagai upaya pencegahan terjadinya ketidaktahuan keuntungan waktu pembagian. Namun ada pula yang membolehkan barang, tetapi dengan syarat barang yang bisa dinilai dengan nominal uang. Jika modal diberikan dalam bentuk aset, maka aset tersebut harus dinilai pada waktu akad.

2) Modal harus jelas dan diketahui jumlahnya

3) Modal harus tunai bukan utang

4) Modal harus diserahkan kepada mitra kerja

Sementara itu, syarat keuntungan yaitu keuntungan harus jelas ukurannya dan keuntungan harus dengan pembagian yang disepakati kedua belah pihak.

e. Implementansi di Bank Syariah

Mudharabah dapat diterapkan pada produk pembiayaan dan penghimpunan dana. Pada sisi penghimpunan dana, mudharabah diimplementasikan pada tabungan berjangka, yaitu tabungan yang dimaksudkan untuk tujuan khusus, seperti tabungan haji, tabungan qurban dan sebagainya. Lalu depostio biasa maupun deposito spesial (special investment), dimana dana yang dititipkan nasabah khusus untuk bisnis tertentu, misalnya murabahah saja atau ijarah saja.

Adapun pada sisi pembiayaan, mudharabah diimplementasikan untuk:

I) Pembiayaan modal kerja, seperti modal kerja perdagangan dan jasa

2) Investasi khusus, disebut juga mudharabah muqayyadah, dimana sumber dana khusus dengan penyaluran yang khusus dengan syarat-syarat yang telah ditetapkan oleh shahibul mal.

I. Musyarakah

a. Definisi Musyarakah

Secara bahasa musyarakah sering disebut dengan syirkah yang bermakna ikhtilath (percampuran), yakni bercampurnya salah satu dari dua harta dengan harta lainnya tanpa dapat dibedakan di antara keduanya. Musyarakah juga bisa berarti seorang mencampur hartanya dengan harta orang lain dengan mana salah satu pihak tidak menceraikan dari yang lainnya.

Sedangkan menurut istilah, musyarakah adalah akad kerjasama antara dua pihak atau lebih untuk suatu usaha tertentu dimana masing-masing pihak memberikan kontribusi dana (amal/expertise) dengan kesepakatan bahwa keuntungan dan resiko akan ditanggung bersama sesuai dengan kesepakatan.

b. Landasan Hukum Islam tentang

Musyarakah

I) Al-Quran

QS. an-Nisa/4: 12

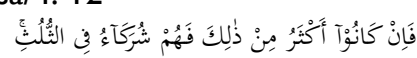

“...Maka mereka bersekutu dalam yang sepertiga itu..."

Ayat al-Quran di atas menjelaskan tentang syirkah al-milk (kepemilikan) yang disebabkan karena warisan.

QS. Shad/38: 24

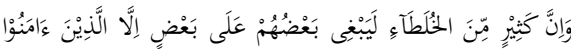

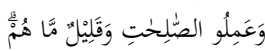

“...Dan sesungguhnya kebanyakan dari orang-orang yang berserikat itu sebahagian mereka berbuat zalim kepada sebahagian yang lain, kecuali orang-orang yang beriman dan mengerjakan amal yang saleh; dan amat sedikitlah mereka ini..."

2) Al-Hadits

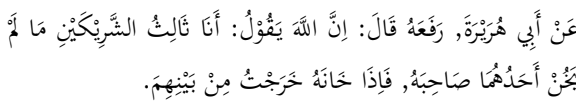

Dari Abu Hurairah, Rasulullah saw. bersabda: "Allah swt. berfirman: 'aku adalah pihak ketiga dari dua orang yang bersyarikat selama salah satu pihak tidak mengkhianati pihak yang lain. Jika salah satu pihak telah berkhianat, Aku keluar dari mereka."” (HR. Abu Daud, yang dishahihkan oleh al-Hakim)

c. Jenis-jenis Musyarakah

Syirkah secara general terbagi menjadi dua jenis, yaitu syirkah amlak (kepemilikan) dan syirkah 'uqud (kontrak). Syirkah amlak adalah perserikatan kepemilikan suatu aset kekayaan bukan karena sebuah kontrak. Syirkah amlak terbagi lagi menjadi dua macam, yaitu syirkah ikhtiyar dan syirkah jabar. Syirkah ikhtiyar (sukarela) adalah syirkah yang timbul karena kehendak dua orang yang berserikat, misalkan dua orang yang menerima hibah atau wasiat dan mereka berserikat atas apa yang mereka terima dalam hak milik, atau dua orang yang sama-sama memutuskan untuk berserikat dalam membeli barang. 
Syirkah jabar (pakasaan) adalah syirkah yang timbul tanpa didahului kehendak (otomatis), misalkan tercipta karena warisan.

Syirkah 'uqud adalah perserikatan dua orang atau lebih yang tercipta karena adanya akad atau kontrak untuk bermitra usaha dengan menerima pembagian keuntungan dan kerugian. Syirkah 'uqud terbagi lagi menjadi empat macam, yaitu syirkah al-inan, syirkah mufawadhah, syirkah a'mal dan syirkah wujuh, kemudian mazhab hambali memasukkan syirkah mudharabah sebagai syirkah yang kelima, sedangkan pendapat lain mudharabah dimasukkan dalam pembahasan tersendiri atau berbeda dengan syirkah.

\section{I) Syirkah al'inan}

Syirkah al-inan adalah kerja sama dua orang atau lebih untuk bermitra usaha dengan bersama memberikan kontribusi modal dan kerja lalu membagi keuntungan diantara mereka.

2) Syirkah al-mufawadhah

Syirkah mufawadhah adalah kerja sama dua orang atau lebih untuk bermitra usaha dengan kesamaan modal, kerja, dan pembagian keuntungan diantara mereka.

3) Syirkah a'mal atau syirkah abdan

Syirkah a'mal adalah kerja sama dua orang untuk menerima suatu pekerjaan yang akan dikerjakan secara bersamasama. Kemudian keuntungan dibagi diantara keduanya dengan menetapkan persyaratan tertentu. Kerjasama ini misalnya diantara dua orang penjahit tukang besai, dan lain-lain.

4) Syirkah Wujuh

Syirkah wujuh adalah kerja sama antara dua orang atau lebih untuk membeli sesuatu tanpa modal, tetapi hanya modal kepercayaan dan keuntungan dibagi antara sesama mereka.

d. Rukun dan Syarat Musyarakah

Rukun dari akad musyarakah yang harus dipenuhi dalam transaksi ada beberapa, yaitu:

I) Pelaku akad, yaitu para mitra usaha

2) Objek akad, yaitu modal (mal ), kerja (dharabah), dan keuntungan (ribh)

3) Shighah, yaitu ijab dan qabul.

Syarat-syarat yang berhubungan dengan syirkah dapat dibagi menjadi syarat yang berlaku umum dan syarat khusus pada jenis syirkah tertentu.

Sesuatu yang bertalian dengan semua bentuk syirkah baik dengan harta maupun dengan yang lainnya. Dalam hal ini terdapat dua syarat, yaitu: a) yang berkenaan dengan benda yang diakadkan adalah harus dapat diterima sebagai perwakilan, b) yang berkenaan dengan keuntungan, yaitu pembagian keuntungan harus jelas dan dapat diketahui dua pihak, misalnya setengah, sepertiga, dan yang lainnya.

Sesuatu yang bertalian dengan syirkah amwal (harta) seperti syirkah al-inan dan almufawadhah dalam hal ini terdapat dua perkara yang harus dipenuhi yaitu: a) bahwa modal yang dijadikan objek akad syirkah adalah dari alat pembayaran (nuqud) seperti junaih, Riyal dan Rupiah, namun dibolehkan dengan barang dengan syarat barang tersebut dinilai terlebih dahulu dengan ukuran nominal uang b) yang dijadikan modal (harta pokok) ada ketika akad syirkah dilakukan baik jumlahnya sama maupun berbeda. Sesuatu yang bertalian dengan syirkah mufawadhah, bahwa dalam mufawadhah disyaratkan: a) modal (pokok harta) dalam syirkah mufawadhah harus sama, jika yang diserahkan berupa dua mata uang yang berbeda, maka harus disamakan dulu nominalnya, b) masing-masing pihak yang berserikat hendaklah cakap untuk kafalah, yakni sama-sama merdeka, berakal dan beragama sama,, c) bagi yang dijadikan objek akad disyaratkan syirkah umum, yakni pada semua macam jual beli atau perdagangan.

e. Implementasi di Bank Syariah

Musyarakah biasanya dapat diaplikasikan untuk pembiayaan proyek di mana nasabah dan bank sama-sama menyediakan dana untuk membiayai proyek tersebut. Setelah proyek itu selesai, maka nasabah mengembalikan dana tersebut bersama bagi hasil yang telah disepakati untuk bank. Selain itu saat ini musyarakah pula dijadikan akad alternatif selain akad murabahah dan istishna' untuk pembiayaan hunian syariah atau pembiayaan pemilikan rumah yang disebut akad musyarakah mutanaqisah. Menurut Fatwa DSN No: 73/DSN-MUI/ XI/2008, Musyarakah mutanaqisah adalah musyarakah atau syirkah yang kepemilikan aset (barang) atau modal salah satu pihak (syarik) berkurang disebabkan pembelian secara bertahap oleh pihak lainnya. Jadi dalam akad ini, bank syariah dan nasabah bersyirkah (berkongsi) dengan sama-sama menyertakan modal dalam pembelian 
suatu aset, misalkan bank syariah dengan modal $65 \%$ dan nasabah dengan modal $35 \%$ dari porsi total nilai harga suatu rumah. Kemudian secara bertahap nasabah mengangsur pembelian porsi modal milik bank syariah.

\section{ANALISIS HUKUM EKONOMI SYARIAH I. Konsep Dasar}

Konsep dasar dari akad mudharabah dan musyarakah adalah sebuah pola operasional yang didasarkan pada asas kerjasama atau pengaplikasian bagi hasil sebagai prinsipnya. Pihak yang bertransaksi bekerjasama dalam bisnis yang dijalankan, kemudian ada ketentuan bagi hasil yang selanjutnya dibagi pada masa yang telah ditentukan pula. Dengan demikian, kerjasama terjadi dan bagi hasil menjadi konsekuensi logisyuridis dalam bisnis yang dijalankan.

\section{Rukun}

a. Mudharabah dalam Produk Penghimpunan Dana

Pelaku akad:

Shahibul mal (pemodal) : Nasabah

Penabung

Mudharib (Pengelola modal)

:Bank Syariah

\section{Objek Akad}

Modal : Dana dari Nasabah Penabung

Kerja : Operasional Bisnis Bank Syariah

Keuntungan : Keuntungan yang dibagi Berdasarkan nisbah bagi hasil

\section{Shighah: ljab dan qabul}

Kontrak tertulis antara nasabah dan Bank Syariah disertai pembicaraan secara lisan

b. Mudharabah dalam Penyaluran Dana

Pelaku akad:

Shahibul mal (pemodal) : Bank Syariah

Mudharib

(Pengelola modal)

:Nasabah Pembiayaan

\section{Objek Akad}

Modal : Dana dari Pembiayaan Bank Syariah

Kerja : Operasional Bisnis Nasabah

Keuntungan : Keuntungan yang dibagi berdasarkan nisbah bagi hasil

\section{Shighah: ljab dan qabul}

Kontrak tertulis antara nasabah dan Bank Syariah disertai pembicaraan secara lisan

c. Musyarakah dalam Penyaluran Dana

Pelaku akad:

Pemberi Modal (Mitra Usaha): Bank Syariah Parsial (Pembiayaan) dan Nasabah (asset value)

\section{Objek Akad}

Modal : Dana dari Pembiayaan Bank Syariah dan asset value milik nasabah Kerja : Operasional Bisnis Nasabah

Keuntungan : Keuntungan yang dibagi berdasarkan nisbah bagi hasil

Shighah: ljab dan qabul

Kontrak tertulis antara nasabah dan Bank Syariah disertai pembicaraan secara lisan

3. Akad Kerjasama dalam Produk Keuangan Syariah

Bank Syariah seperti Bank pada umumnya merupakan lembaga keuangan yang bergerak dengan tiga fungsi utama, yakni penghimpunan dana, penyaluran dana dan jasa. Produk-produk keuangan yang ditawarkan oleh Bank Syariah memiliki konsep dasar yang membedakan dengan Bank Konvensional yaitu pada perihal akad. Akad-akad yang digunakan dan diterapkan adalah akad yang harus sesuai dengan syariat Islam atau dapat disebut merupakan perjanjian dalam ekonomi syariah.

Salah satu bentuk akad dalam ekonomi syariah yakni akad berpola kerjasama. Dalam ekonomi syariah, dikenal berbagai akad berpola kerjasama seperti:

a. Mudharabah

b. Musyarakah/syirkah

c. Muzara'ah

d. Mukhabarah

e. Musaqah

Diantara berbagai bentuk akad berpola kerjasama di atas, akad yang digunakan dan diterapkan sebagai konsep Islam dalam Bank Syariah yaitu akad mudharabah dan musyarakah.

4. Implementasi Akad mudharabah di Bank Syariah

Mudharabah di Bank Syariah diaplikasikan dalam bentuk produk pendanaan (antara nasabah penabung [deposan] dengan Bank) dan pembiayaan (antara Bank dengan nasabah pembiayaan).

Produk Pendanaan (penghimpunan dana) yakni tabungan dan deposito. Lalu produk Pembiayaan (penyaluran dana), maka mudharabah diaplikasikan dalam bentuk pembiayaan modal kerja (usaha produktif baik barang maupun jasa). Dapat pula pada investasi khusus, yakni investasi yang diberikan dengan syarat-syarat tertentu dari pihak pemilik dana seperti menjalani bisnis atau usaha tertentu saja.

5. Implementasi Akad Musyarakah di Bank Syariah

Akad musyarakah diimplementasikan pada pembiayaan proyek, dimana bank dengan nasabah sama-sama memberikan kontribusi modalnya masing-masing pada 
proyek usaha tertentu. Bank dan nasabah menjadi mitra usaha dan selanjutnya biasanya Bank disebut mitra pasif dan nasabah disebut mitra aktif dalam praktiknya. Hal ini dikarenakan nasabah selain sebagai pemilik modal juga bertindak sebagai pengelola usaha dengan keterampilannya melakukan pengelolaan sedangkan bank tidak ikut secara langsung dalam kegiatan usaha melainkan ikut dalam arti hanya dalam bentuk penyertaan modal dan melakukan sesuatu sesuai tugas dan wewenang yang disepakati seperti melakukan review, meminta bukti dari laporan hasil usaha yang dibuat oleh nasabah berdasarkan bukti pendukung yang dapat dipertanggung jawabkan.

\section{Kajian Hukum Ekonomi Syariah}

Berbisnis merupakan cara dalam mencari dan mendapatkan rezeki dari Allah swt. bisnis merupakan bagian dari bermuamalah, yang mana Allah telah mensyariatkan aturan atau ketentuan hukum tidak hanya terbatas pada perkara ibadah tetapi juga pada perkara muamalah, karena memang Islam adalah agama yang universal dan komprehensif.

Berbeda dengan perkara ibadah, kaidah fikih yang menjadi dasar secara umum dari kegitatan muamalah yakni:

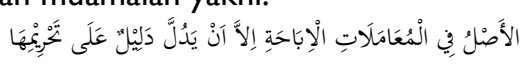

"Hukum asal muamalah adalah boleh, terkecuali ada dalil yang mengharamkannya."

Artinya selama kegiatan ekonomi tersebut tidak ada pelarangan dan tidak unsur-unsur terlarang didalamnya, maka hal itu dibolehkan untuk dilaksanakan. QS. alBaqarah/2: 275

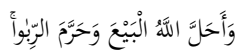

"Dan Allah telah menghalalkan jual beli dan mengharamkan riba."

Ayat di atas menyebutkan bahwasanya Allah menghalalkan jual beli dan mengharamkan riba. Riba merupakan salah satu unsur terlarang yang tidak boleh ada dalam muamalah, maka tidak dibenarkan unsur melakukan tambahan yang sifatnya riba dalam berbisnis seperti pinjaman uang berbunga.

Mudharabah dan musyarakah merupakan akad berpola kerjasama, berbeda dengan akad hutang-piutang yang disebut qardh. Mudharabah dan musyarakah termasuk dalam jenis akad tijarah (komersial), sedangkan qardh bagian dari akad tabarru (sosial) dan dikategorikan dalam akad tathawwu'i atau akad saling membantu dan bukan transaksi komersial. Akad tijarah memang akad bisnis yang orientasinya profit, maka dari itu tambahan yang terdapat dalam mudharabah dan musyarakah termasuk dalam pendapatan yang halal berupa bagi hasil keuntungan. Eksistensi akad mudharabah dan musyarakah dalam transaksi keuangan memiliki legalitas hukum dalam kajian fikih muamalah baik itu disandarkan pada dalil naqli (al-Quran dan al-Hadits) maupun dalil aqli atau metode ijtihad penalaran syar'i yakni ijma ddan qiyas.

Berbeda halnya dengan mudharabah dan musyarakah, akad qardh atau pinjaman uang yang terdapat tambahan di dalamnya (utang-piutang berbunga) seperti dipraktikkan bank konvensional, maka bunga dalam pinjaman tersebut merupakan tambahan yang bathil sebab merupakan riba yang diharamkan. Bunga bank termasuk dalam kategori riba yang dilarang dalam Islam baik dalam nominal rendah maupun berganda, dalam jumlah banyak maupun sedikit, serta dalam pinjaman konsumtif maupun produktif seperti yang diungkapkan Yusuf alQaradhawi dalam fawa'id al-Bunuk Hiya ar-Riba al-Haram, Wahbah az-Zuhaili dalam al-Figh alIslami wa Adillatuh dan Rafiq Yunus al-Mishri dalam Riba al-Qurudh wa Adillah Tahrimih.

Kaidah fikih pula berbunyi:

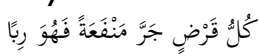

"Setiap pinjaman uang yang mendatangkan manfaat adalah riba."

Kadi Abd al-Wahab al-Maliki dalam kitabnya al-lsyraf mengungkapkan dengan:

$$
\text { كُلُ قَرْضٍ جَرَّ نَفْعًا فَهُوَ حَرَامُ }
$$

\begin{tabular}{|c|c|}
\hline \multicolumn{2}{|c|}{ Perbedaan Bagi Hasil dan Bunga } \\
\hline BAGI HASIL & BUNGA \\
\hline Akad kerja sama & $\begin{array}{l}\text { Akad pinjaman/utang- } \\
\text { piutang }\end{array}$ \\
\hline $\begin{array}{l}\text { Dihitung dari } \\
\text { keuntungan usaha yang } \\
\text { didapatkan }\end{array}$ & $\begin{array}{l}\text { Dihitung dari pokok } \\
\text { utang }\end{array}$ \\
\hline Bersifat Fluktuatif & Bersifat fix (tetap) \\
\hline Pendekatan sektor riil & $\begin{array}{l}\text { Pendekatan sektor } \\
\text { moneter }\end{array}$ \\
\hline Sah & Bathil \\
\hline Halal & Haram \\
\hline
\end{tabular}

"Setiap pinjaman uang yang mendatangkan manfaat adalah haram."

Implementasi akad mudharabah dan musyarakah sendiri dalam produk keuangan modern saat ini salah satunya diterapkan di Bank Syariah. Implementasi akad mudharabah adalah pada produk pendanaan dan pembiayaan, sedangkan akad musyarakah pada produk pembiayaan saja.

Seperti telah disebutkan sebelumnya pada poin pembahasan rukun akad, maka praktik di Bank Syariah dalam analisis penulis telah 
diuraikan bahwa telah terpenuhi semua rukun akad baik dalam produk keuangan berakad mudharabah maupun musyarakah.

Kerjasama antara Bank Syariah dan nasabah baik pada akad mudharabah dan musyarakah, terlebih dahulu sebelum dijalankan, akan dilakukan persetujuan kontrak, ketika setuju akan diteruskan, jika tidak maka tidak akan diteruskan. Ini berarti saat nasabah telah menggunakan produk keuangan dari Bank Syariah, artinya nasabah telah melakukan kesepakatan dengan Bank Syariah yang menunjukkan terwujudkanya prinsip 'an taradhin (saling ridha/suka sama suka). QS. an-Nisa/4: 29

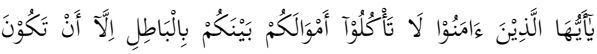

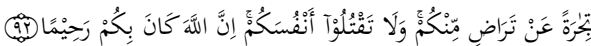

"Hai orang-orang yang beriman, janganlah kamu saling memakan harta sesamamu dengan jalan yang batil, kecuali dengan jalan perniagaan yang Berlaku dengan suka sama-suka di antara kamu. dan janganlah kamu membunuh dirimu; Sesungguhnya Allah adalah Maha Penyayang kepadamu."

Rasulullah saw. pula bersabda:

$$
\text { إنَّمَا الْبَيْعُ عَنْ تَرَاضٍ. }
$$

"Sesungguhnya jual beli itu harus berdasar pada saling ridha."

Dalam sebuah kaidah fikih menyebutkan:

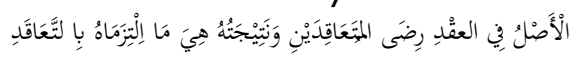

"Hukum asal pada akad adalah keridhaan kedua belah pihak yang mengadakan akad, hasilnya apa yang saling diiltizamkan (diikatkan) oleh perakadan itu".

Lalu kaidah derivasinya:

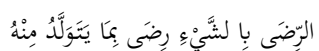

"Keridhaan dengan sesuatu adalah ridha dengan akibat yang terjadi dari padanya

Keberadaan akad mudharabah dan musyarakah, memiliki manfaat baik dari sudut pandang Bank Syariah, maupun nasabah yang terbantu dengan adanya suntikan dana dalam usaha produktif yang dijalankan.

\section{SIMPULAN}

Berdasarkan kajian dalam paparan sebelumnya, maka dapat disimpulkan sebagai berikut:

I. Implementasi akad berpola kerja sama pada Bank Syariah yakni mudharabah adalah pada produk penghimpunan dana (tabungan dan deposito) dan pembiayaan modal kerja, sedangkan musyarakah pada produk pembiayaan saja.
2. Implementasi akad mudharabah dan musyarakah di Bank Syariah dalam kajian hukum ekonomi syariah adalah boleh dilakukan, dikarenakan akad mudharabah dan musyarakah merupakan akad berpola kerja sama yang sesuai dengan syariat Islam. Lalu implementasinya harus memenuhi rukun dan syarat sah akadnya baik dalam produk penghimpunan dana maupun pembiayaan.

\section{DAFTAR PUSTAKA}

Al-Khasrujardi Ahmad bin Husain bin 'Alî bin Mûsa (Abû Bakar al-Baihaqi). as-Sunan al-Kubrâ, Juz 6. Beirut: Dâr al-Kutuûb al'Ilmiyyah, 2003.

Al-Mishrî, Rafiq Yunus. Ribâ al-Qurûdh wa Adillah Tahrîmih. Damaskus: Dâr al-Maktabî, 2009.

Al-Mushlih, Abdullah., dan Shalah ash-Shawi. Fikih Ekonomi Keuangan Islam. Terj. Abu Umar Basyir. Jakarta: Darul Haq, 2004.

Al-Qazwaini, Ibnu Mâjah Abû 'Abdullah bin Muhammad Yazîd. Sunan Ibnu Mâjah, Juz 2. Cairo: Dâr lhyâ al-Kitâb al-'Arabiyyah, t.t.

Al-Qaradhâwî, Yûsuf. Fawâ’id al-Bunûk hiya arRibâ al-Harâm. Kairo: Dâr al-Shahwwah, 1994.

An-Naisâbûrî, Abû 'Abdullah Muhammad bin 'Abdullah al-Hakim. Al-Mustadrak 'Alâ ashShahîhain, Juz 2. Beirut: Dâr al-Kutub al'Ilmiah, 1990.

Antonio, Muhammad Syafi'i. Bank Syariah: Dari Teori ke Praktik. Jakarta: Gema Insani, 2015.

Ariyadi A. Bisnis Dalam Islam. Jurnal Hadratul Madaniyah. 2018 Jun I;5(I): I3-26.

Ascarya. Akad dan Produk Bank Syariah. Jakarta: RajaGrafindo Persada. 2012.

As-Sijistânî, Abû Dâwud Sulaimân bin al-Asy'ats bin Ishâk al-Azdî. Sunan Abû Dâwud, Juz 3. Beirut: al-Maktabah al-'Ashriyah, t.t.

At-Tamîmî, Muhammad bin Hibbân bin Ahmad bin Hibbân bin Mu'adz bin Ma'bad. Shahîh Ibnu Hibbân, Juz II. Beirut: Muassasah ar-Risâlah, 1988.

Ath-Thabrânî, Abû al-Qâsim Sulaimân bin Ahmad al-Lakhmî. Al-Mu’jam Al-Ausath, Juz I. Kairo: Dâr al-Haramain, t.t.

Az-Zuhailî, Wahbah. al-Figh al-Islâmî wa Adillatuh, Juz 4. Damaskus: Dâr al-Fikr, 1989.

Azhari, Fathurrahman. Qawaid Fiqhiyyah Muamalah. Banjarmasin: Lembaga Pengembangan Kualitas Ummat, 2014.

Djazuli, A. Kaidah-kaidah Fikih. Jakarta: Kencana, 2010.

Janwari, Yadi. Lembaga Keuangan Syariah. Bandung: Rosdakarya. 2015. 
Muhammad Syarif Hidayatullah.2020. Implementasi Akad Berpola Kerja Sama Dalam Produk Keuangan Di Bank Syariah (Kajian Mudharabah Dan Musyarakah Dalam Hukum Ekonomi Syariah)

Karim, Adiwarman A. Bank Islam: Analisis Fiqih dan Keuangan. Jakarta: RajaGrafindo, 2007.

Suhendi, Hendi. Fiqih Muamalah. Jakarta: RajaGrafindo Persada. 2014. 